\title{
Regulamentação financeira e bancária
}

\author{
Paulo Gaya*
}

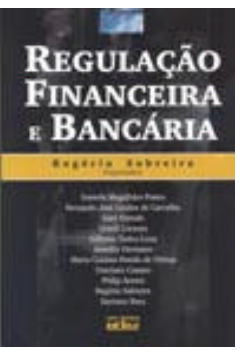

SOBREIRA, Rogério (Org.). Regulação financeira e bancária. São Paulo: Atlas, 2005. ISBN 85-224-3940-0

Quando episódios como a recente liquidação do Banco Santos ocorrem, não são raras as vezes em que se levanta a discussão sobre a pertinência do controle do Estado sobre os bancos, tanto em termos de fiscalização quanto de regulação. No que diz respeito à regulação, duas correntes defendem posições distintas. Uma, o controle mínimo, deixando que o mercado bancário se auto-ajuste. A outra corrente, um controle mais rígido sobre a atividade bancária, que é o ponto de vista adotado em Regulação financeira e bancária.

Para defender esse ponto de vista, o professor Rogério Sobreira, da Escola Brasileira de Administração Pública e de Empresas, da Fundação Getúlio Vargas (Ebape/FGV), reuniu um time de 11 pesquisadores, brasileiros e estrangeiros, que ao longo de 10 capítulos enfocam vários aspectos do tema em questão. A primeira parte, composta por seis capítulos, expõe argumentos que justificam a regulação dos bancos e analisa alguns casos práticos. A segunda parte, reunindo os quatro capítulos finais, discute como os países emergentes podem lidar com a regulação financeira e como são afetados por ela.

O livro começa com Maria Cristina de Freitas justificando a necessidade do controle do Estado sobre as instituições bancárias, devido ao papel fundamental dos bancos no sistema capitalista, tanto como fornecedores de crédito quanto por exercerem intermediação financeira. No capítulo dois, Philip Arestis e Santonu Basu falam das diferenças entre os conceitos de liberalização e globalização financeira. Ainda nesse capítulo, é defendida a idéia de que para atingir a globalização financeira são necessárias uma moeda única global e instituições internacionais que coordenem e regulem as instituições financeiras dos diversos países.

No capítulo três, Rogério Sobreira nos mostra que possíveis ganhos obtidos pela desregulamentação seriam anulados pela instabilidade que passa a atingir o sistema financeiro; um sistema que de fato, funciona como uma engrenagem em que se uma parte falhar, o todo é afetado. Nesse sentido, a citação de Minsky ilustra bem a situação: "o funcionamento normal da economia capitalista depende da geração de lucros do sistema produtivo para pagar os empréstimos e do sistema financeiro fazer empréstimos que levem ao investimento e daí ao lucro".

No quarto capítulo, Gentil Corazza questiona a supervisão bancária, que por melhor que seja é incapaz de impedir crises periódicas, fazendo a ressalva de que, apesar disso, historicamente, corre-se um risco maior com a auto-regulação. Temos também uma análise sobre a recomendação do Comitê de Basiléia para que as agências de supervisão bancária sejam independentes, e podemos verificar como vários países atuam nessa área, com a observação de que essas agências podem fazer parte do Banco Central, sem necessidade de serem órgãos separados.

No capítulo seguinte temos Gary Dymski apresentando os resultados da desregulamentação no mercado americano; basicamente, um processo de centralização e fusões que resultou na exclusão da população de menor ren-

* Mestrando em Administração Pública pela EBAPE/FGV. E- mail: paulo@ gaya.por.br. Endereço: Praia de Botafogo 190 - 50 andar - Rio de Janeiro - CEP $22253-900$. 
da do mercado bancário, o que representou uma perda econômica e social. Fechando a primeira parte, o capítulo de Fernando de Carvalho mostra a evolução recente da regulação, até o acordo de Basiléia II, que abre caminho para que as próprias instituições financeiras definam e avaliem seus riscos.

Quanto à segunda parte, esta apresenta uma análise mais prática dos efeitos da regulação, principalmente nos países emergentes. Começa com Maria Cristina de Freitas e Daniela Prates examinando as consequiências das mudanças estabelecidas pelo Comitê de Basiléia. A análise mostra um conflito que atinge os países emergentes, uma vez que se essas regras deixam as instituições financeiras menos vulneráveis ao risco, reduzindo a possibilidade de crises, por outro lado, acabam difilcutando o acesso dos países emergentes aos financiamentos no mercado internacional, o que pode levar à crise que se tenta evitar. Assim, em algumas situações, tais medidas podem ter efeito contrário ao pretendido.

No capítulo seguinte, Otaviano Canuto e Gilberto Lima mostram a importância de se dispor de adequadas instituições regulatórias, afinadas com as políticas fiscal, monetária e cambial; um arcabouço que pode mitigar os efeitos de crises internacionais, ainda que não possa anulá-los completamente.

O nono capítulo, "Evolução recente da regulação bancária no Brasil", de Gilberto Lima, mostra como o país acompanhou o processo de globalização financeira e os acordos de Basiléia.

Jennifer Herman fecha o livro com o último e mais longo capítulo, mostrando a abertura financeira ocorrida no Brasil entre 1987 e 1999 e lembrando como o país reagiu às crises internacionais nesse período, até o momento em que adotou o câmbio flutuante.

Um ponto que é ressaltado ao longo de Regulação financeira e bancária é a necessidade da regulação bancária ligada ao risco moral dos bancos. Tendo em vista que o Banco Central é o prestamista de última instância, as instituições são levadas a um comportamento mais arriscado nas suas atividades, confiando na rede de segurança do BC. A regulação bancária é necessária justamente para diminuir esse risco moral; argumento já bastante forte para justificar a regulamentação do mercado.

Regulação financeira e bancária é, portanto, um livro do interesse de todos aqueles que estão ligados ao mercado bancário, inclusive dos próprios bancos, mas especialmente das instituições governamentais responsáveis pela regulação. Deve ser lido pelos que defendem a liberalização financeira, para que reflitam sobre seus argumentos, mas pode igualmente interessar aos envolvidos na regulamentação do artigo 192 da Constituição Federal. 